Eskişehir Osmangazi Üniversitesi iißBF Dergisi

Ağustos 2019, C. 14, S. 2, 535 - 558.

Başvuru : : 10.03.2019

Kabul : :26.07.2019

\title{
Uluslararası Düzensiz Göç ve Çalışma Hayatı: Şanlıurfa illindeki Suriyeli Göçmenlerin Durumu ${ }^{1}$
}

\author{
Ozan Ağlargöz ${ }^{2}$ \\ Şehmus Yardımcı ${ }^{3}$
}

Uluslararası Düzensiz Göç ve Çalışma Hayatı: Şanlıurfa ìlindeki Suriyeli Göçmenlerin Durumu

Öz

Bu çalışmanın amacı 2011 yılında Suriye'de yaşanan iç savaş nedeniyle ortaya çıkan düzensiz uluslararası göçün çaışma hayatı bağlamında durumunu betimlemektir. Çaışma, Suriye kaynaklı göçten en çok etkilenen ve Suriyeli göçmenlerin en yoğun olarak yaşadığı illerden birisi olan Şanlıurfa ilinde gerçekleştirilmiştir. Araştırma, yöntem olarak durum çalışması şeklinde tasarlanmıştır. Veri elde etme tekniği olarak yarı-yapılandırılmış görüşme kullanılmıştır. Veriler, betimsel analiz yoluyla analiz edilerek yorumlanmıştır. Çalışma sonucunda Suriyeli göçmen çalışanların; iş bulma ve çalışma yeri seçiminde, işletmelerinin kuruluş yeri seçiminde ve göç edilecek yer seçiminde, akrabalık bağları ile Suriyelilerin yoğun olarak yaşadıkları yerlerin belirleyici olduğu görülmüştür. Ayrıca göçmenlerin çalışma koşulları, istihdam edilme sebepleri ve çalışma hayatında yaşadıkları sorunlar ortaya konmuştur.

Anahtar Kelimeler: Düzensiz göç, Çalışma hayatı, Suriye, Şanlıurfa.
International Irregular Migration and The Working Life: The Case of Syrian Immigrants in Şanlıurfa Province

\section{Abstract}

The purpose of this study is to describe the case of working life affected by the international irregular migration caused by the Syrian civil war, which was started in 2011. The study was conducted in Şanlıurfa province of Turkey, which is one of the most affected cities from the Syrian migration and where Syrian immigrants mostly reside. The research is designed as a case study. The empirical material of the study was generated using semi-structured interviews, which then descriptively analyzed and interpreted. Findings revealed that kinship and already-settled Syrian migrant population is found to be determinant on job finding and workplace choice, location selection for entrepreneurs, and decisions on migration destination. Current situation of the working conditions, reasons for employment, and the problems associated with working life experienced by immigrant workers were exposed.

Keywords: Irregular migration, Working life, Syria, Şanlıurfa.

\section{Giriş}

Göç hem bölgesel hem de küresel anlamda ülkeleri derinden etkileyen dinamik bir olgudur. Dünyanın farklı yerlerinde meydana gelen savaşlar, doğal afetler, toplumsal ve siyasal gelişmeler, ekonomik sorunlar, kutuplaşmalar ile teknoloji, ulaşım ve iletişim alanında meydana gelen yenilikler gerek bireysel gerekse kitlesel göç hareketlerinin başlamasına neden olmaktadır. Tüm bu sebeplerden dolayı göç, bulunduğu yeri değiştirmek, daha rahat bir hayat, daha iyi koşullar altında yaşamak ve daha iyi iş imkânlarını elde etme amacını taşımaktadır. Türkiye coğrafi konumu itibariyle hem transit hem de hedef ülke olarak göç hareketlerinden etkilenmektedir (Canefe, 2016). Bu durum Türkiye için bazı sorunları beraberinde getirmektedir.

2011 yılıyla birlikte meydana gelen Suriye kaynaklı göç; II. Dünya Savaşı'ndan sonraki dönemde yaşanan küresel ölçekteki en büyük göç hareketi olmasının yanında, Türkiye için Cumhuriyet sonrası dönemdeki en büyük göç hareketi olması yönüyle de dikkat çekmektedir (Bahçekapılı ve Çetin, 2015). Bu çalışmanın amacı, Suriye kaynaklı düzensiz göçün genelde Türkiye

\footnotetext{
${ }^{1}$ Bu çalışma Dr. Öğr. Üyesi Ozan Ağlargöz danışmanlığında yürütülen, Şehmus Yardımcı'nın “Çalışma Hayatı Uluslararası Düzensiz Göçle Karşılaştığında: Şanlıurfa Illindeki Suriyeli Göçmenlerin Durumu” başlıklı yüksek lisans tezinden türetilmiştir.

2 Dr. Öğr. Üyesi, Anadolu Üniversitesi iiBF, İşletme Bölümü. ozanaglargoz@anadolu.edu.tr,yazar ORCID bilgisi: https://orcid.org/0000-0001-5523-4451.

${ }^{3}$ Gümrük Muhafaza Memuru, T. C. Ticaret Bakanlığı. sehmusyardimci@hotmail.com, yazar ORCID bilgisi: https://orcid.org/0000-0002-0421-129X.
} 
üzerindeki etkisi, özelde ise Suriyelilerin yoğun olarak yaşadığı illerin başında gelen Şanlıurfa'da, göçten etkilenen işletme, işveren ve iş̧̧i gibi tarafların incelenmesi ve yaşanan durumun betimlenmesidir. Araştırma, Suriye'den gelen kitlesel göç hareketinden dolayı Şanlıurfa'daki işgücü ve işletmelerde meydana gelen değişim ve bu değişimin getirdiği olumsuzlukların ortaya çıkarılması açısından önem arz etmektedir. Suriyeli göçmen istihdam eden işletme sahipleri, Suriyeli göçmen çalışanlar ve Suriyeli girişimcilerden elden edilen verilerle göç olgusunun çok yönlü bir bakış açısıyla incelenmesi sağlanmıştır. Böylelikle konuya ilişkin tüm paydaşların görüşleri doğrultusunda, mevcut durum zengin bir şekilde betimlenmiştir. Devam eden bölümlerde; öncelikle çalışmanın temelini oluşturan alanyazından söz edilecek, çalışmanın yürütüldüğü bağlam betimlenecek, araştırma sürecindeki metodolojik tercihlerin sebepleri açıklanacak, çalışma kapsamında elde edilen bulgular ve bulgulara ilişkin yorumların paylaşılmasından sonra çalışma sonuç ve önerilerin sunulmasıyla son bulacaktır.

\section{2. İgili Alanyazın}

Göç, farklı disiplinler tarafından araştırılan bir konu olduğu için alanyazında göç kavramına ilişkin farklı tanımlara rastlanmaktadır. Kavramın net bir şekilde anlaşılabilmesi için göçe ilişkin farklı tanımların üzerinde durulması gerekmektedir. Göç; toplulukların veya bireylerin ekonomik, siyasi, dini ve sosyal sebeplerden ötürü yerleşim maksadıyla başka bir yere gitme hareketlerini tanımlamak için kullanılmaktadır. Göç hareketleri ülke içerisinde ise iç göç, ülke dışında ise dış göç veya uluslararası göç olarak anılır. Göç, aynı zamanda göçmenlerin, göç edilen ülkede belli bir süre yaşamlarını sürdürme durumları olarak da ifade edilebilir (Çakır, 2011: 210). Beşerî coğrafya açısından göç mekân ile ilişkilendirilirken, demografik açıdan nüfus baz alınarak incelenmektedir. İktisatta ise göç olgusu, üretim faktörlerinin uluslararası düzeyde geçişi olarak ele alınmaktadır. Bütün farklı bakış açıları bütüncül bir şekilde irdelendiğinde göçün ekonomik, sosyal ve siyasal etki alanları olan bir kavram olduğu ortaya çıkmaktadır (Aydoğanoğlu, 2007: 4). Günümüzde göç çalışma hayatında yeni bir prekaryanın oluşumunu tetiklemektedir (Canefe, 2016). Fakat istemli ve/veya istem dışı yer değiştirme olarak ifade edilebilen göç olgusunda temel motivasyonun daha iyi bir gelecek hayali olduğu unutulmamalıdır (Cengiz, 2015: 105).

Düzensiz ve yasadışı göçmenler ise yabancıların yasa dışı yollarla Türkiye'ye girişini, Türkiye'de kalışını, Türkiye'den çıkışını ve Türkiye'de izinsiz çalışmasını ifade eder. (Yabancılar ve Uluslararası Koruma Kanunu [YUKK], Md. 3 (ı) (Göç İdaresi Genel Müdürlüğü [GiGM]: 42). Herhangi bir yasal dayanağı olmayan düzensiz göç, göç edilen ülke için ekonomik ve sosyal sorunlar başta olmak üzere birçok alanda büyük değişimlere neden olmaktadır. Yakın zamanda Suriye'de meydana gelen olaylardan dolayı Türkiye'ye yönelen göç hareketinin çoğunluğunu, bu ülke kökenli göçmenler oluşturmaktadır.

Göç kavramının tam olarak anlaşılabilmesi için bazı göç kuramlarına değinmek yerinde olur. Kuramlar, göç olgusunun çok yönlü ve bütüncül bir şekilde açıklanması açısından oldukça önemlidir. Göç olgusuna ilişkin olarak bu çalışma kapsamında uluslararası göçe ilişkin; uluslararası itme-çekme modeli, göç sistemleri teorisi ve Ravenstein göç kanunları üzerinde durulmuştur. Lee'nin (1966) "Göç Teorisi" adlı araştırmasında, bireylerin ya da toplulukların göç kararını vermesinde belirleyici çeşitli etmenlerin olduğuna işaret edilmektedir. Bunlar; menşe yer ile gidilecek yere ilişkin olumlu, olumsuz ve nötr faktörler ile değişime açık olmak gibi kişilik özellikleri ve uzaklık, göç yasaları gibi araya giren sınırlayıcı engellerdir (Lee, 1966: 50-51). Lee'nin (1966) ifade ettiği itici faktörler; demografik, siyasal, ekonomik ve yaşam standardının istenilen düzeyde olmamasını içermektedir. Çekici faktörler ise emek gücü talebi ve ekonomik fırsatları içermektedir. Bu teorinin temel amacı, dezavantajlı insanların gelişmemiş fakir ülkelerden gelişmiş 
zengin ülkelere doğru olan göçlerinin açıklanabilmesidir. Teori, insanların neden düşük ücretli olan çalışma yerlerinden ayrılıp, yüksek ücretli yerlere göç ettiklerini açıklamaktadır. Teori'ye göre; uluslararası gelişmişlik düzeyi, göç hareketlenmelerinin önemli bir belirleyicisidir (Lordoğlu vd. 2004: 10).

Göç sistemleri teorisi, karşılıklı bir şekilde göçmen ilişkisi bulunan ülkeleri konu edinmektedir. Göç sistemleri teorisi ülkeler arasındaki bağlantıların, toplumsal ilişkilerin ve sosyal aile ağlarının incelenmesine olanak tanımaktadır (Fawcett ve Arnold, 1987: 456-457). Akraba ve aile kökenli bağlar göçün karar verme aşamasında etkili olan nedenler arasındadır. Bu süreçte aile bağlarının destekleyici ve yol gösterici unsurları ön plana çıkmaktadır. Göçün temelinde yatan; emek gücü ihtiyacının karşılanmasıdır. Göç olgusunu anlayabilmek için Castles ve Miller (2008: 39-40) aşağıda sıralanan soruların cevaplandırılması gerektiğini belirtmektedir:

- Sosyal, siyasal, demografik ve ekonomik unsurlar ne ölçüde değişiyor ki göçe ilişkin karar alınabiliyor?

- Göç edilen yerin çekici ve cazip gelen faktörleri nelerdir?

- Göç alan ve göç veren ülkeler arasındaki bağlantılar nasıl gerçekleşmektedir?

- Göç ile ilgili mevcut veya düzenlenen mevzuat, sosyal yapı ve uygulamalar nelerdir?

- Göçmenlerin uyum süreci ve yerleşmeleri nasıl gerçekleşmektedir? Bazen ırkçı bazen ise çok kültürlü bir birliktelik nasıl sağlanmaktadır?

- Göçmen alan ülkedeki değişiklikler, oradaki yerleşik halk üzerinde ne gibi etkilere yol açmaktadır?

- Göçmen veren ülkedeki yapı nasıl değişmektedir?

- Göç alan ve göç veren toplumlar arasındaki bağlantılar hangi yeni boyutlara neden olmaktadır?

Göç konusunda oldukça tarihsel bir belge, Ravenstein Kanunları olarak anılan belgedir. Ravenstein tarafından, 1885 'te yayımlanan göç kanunları 7 madde altında toplamıştır. Bunlar;

1. Kısa mesafeli göçlerle insanlar, gidilen ülkede göç dalgası etkisi yaratır.

2. İkinci maddede belirtilen hususlar yakınlık mesafesi ile yani 1 . maddede açıklanan kısa mesafe durumu ile de yakından ilişkilidir. Ekonomik gelişmenin fazla olduğu kentler göçün bu merkezlere doğru akmasına neden olmaktadır. Şehirlere yakın olan ve bundan haberi olan insanlar da kırsal alandan ekonomik dolgunluğun arttığı şehirlere doğru göç etmektedir. Kırsal alanlardaki işgücü açığı da bununla birlikte artmaktadır.

3. Şehirlerin, gelişen ekonomik süreçlerine işgücü bulabilmek ile iş arayan kesimin buluşması için de göç, bir tamamlama görevi görmektedir. Her iki kesimi birbiriyle buluşturan göç, amaca ulaşmak açısından uyumludur.

4. Göç alma eğiliminde olan şehirler aynı zamanda göç de verir.

5. Kısa mesafeli göçlerin aksine, uzun mesafeli göç etmek isteyenlerin tercihleri, daha çok ticaret ve endüstri açısından cazibe merkezlerinden yanadır.

6. Göç alan kentlerin göç verme durumu göz önüne alındığında, göç vermenin daha az gerçekleştiği ortaya çıkmaktadır.

7. Ravenstein göçün, cinsiyet ile ilişkisi üzerinde durmuştur. Kadınların kısa mesafeli göçlere, erkeklerin ise uzun mesafeli göçlere doğru eğilim gösterdiğini belirtmektedir (Ravenstein,1885'ten aktaran Yalçın, 2004: 25). 
Çalışmanın kuramsal altyapısı bağlamında farklı kuramlara ilişkin açıklamaların ardından göçü çalışma hayatı açısından değerlendiren çalışmaların üzerinde durulmalıdır. Kişilerin, geçici veya daimî olarak başka bir ülkeye yerleşmek üzere menşe ülkelerinden veya ikamet ettikleri ülkeden ayrılmaları, dolayısıyla uluslararası bir sınırın geçilmesi uluslararası göçün temelini oluşturmaktadır (IOM, 2009: 59). Küreselleşen dünyadaki göç hareketlerini genellikle Afrika gibi az gelişmiş ülkelerden sadece başka bir yere yerleşmek ya da gidilen ülkede asimile olmakla açıklamak yetersizdir. Çünkü göç olayı hem geriye kalan hayatı hem de ondan sonraki hayatı etkileyen uzun süreli bir ilişkilidir. Göç, toplumsal değişimle meydana gelen kolektif bir yapıdır (Castles ve Miller, 2008: 29). Suriye kaynaklı göç ise uluslararası göç özelliği taşıması nedeniyle hem uluslararası hem devletler arası ilişkileri etkilemektedir. Uluslararası göç, göç alan ülkeler açısından başta güvenlik olmak üzere, ekonomik ve politik sorunlara da yol açmaktadır (Weiner, 1985: 441-455). Toplumlarda göçmenlere karşı gösterilerin artması, önyargıların çoğalması devletleri tedirgin etmekte ve çeşitli sorunların ortaya çıkmasına zemin hazırlamaktadır. Dolayısıyla ulusların alacakları göç kararları çok yönlü olabilmektedir (Boz, 2016: 2). Türkiye'ye yönelen göçlere bakıldığında, göçmenlerin çoğunun komşu ülkelerden geldiği görülmektedir. Bunun en önemli nedeni, tarihsel bağlardır. İran ve Suriye gibi ülkelerden gelen göçün altında yatan faktörlere bakıldığında ise, kimi zaman siyasi kimi zaman gelir amaçıı kimi zaman da batıya geçiş yapma amacından dolayı Türkiye'nin tercih edildiği belirtilebilir. Kuzey ülkelerinden ülkemize olan göç, çıkar ve çalışma amaçlı; Afganistan, Pakistan ve Kenya gibi uzak ve güneydeki ülkelerden gelen göç ise daha çok bir geçiş güzergahı olarak kullanma amacı taşımaktadır (Çakılcı, 2017: 465-466).

Göç olgusunu göçten daha yoğun olarak etkilenen bölgeler açısından araştırma konusu yapan çalışmalar da mevcuttur. Kaynak (2016) Suriye kökenli göçün özellikle sınırda bulunan Şanlıurfa üzerindeki sosyal ve ekonomik boyutunun yanında Suriyeli göçmenlerin yaşadığı olumsuzlukların ve beklentilerinin ortaya çıkarıldığı bir çalışma yürütmüştür. Araştırma sonuçlarına göre göçmenler, Türkiye'de hoş karşılandıklarını, durumlarından memnun olduklarını belirtmektedirler. Katılımcılar işsizlik ve kira sorunlarına rağmen özellikle sınır illerindeki yakınlık ve kültürel değerlerin benzer olmasından dolayı uyum sağlamanın güç olmadığını belirtmişlerdir. Diken ve Demirel'in (2016) yaptıkları çalışmada Suriyeli göçmenlerin kayıt dışı istihdam edildiği ve düşük ücretlerle çalıştırıldığı görülmüştür. Suriyeli göçmenlerin vasıfsız iş alanlarında çalışarak, Türkiyeli iş görenlerin çalışmak istemediği iş alanlarındaki açığı kapattığı ortaya çıkmıştır. Suriyeli göçmenlerin eğitim, sağlık, barınma ve iş bulma konularında aralarında kurdukları sosyal ağları kullandıkları ifade edilmektedir (Yaman, 2016). Oytun ve Şenyücel-Gündoğar (2015) Suriyeliler, iş dünyası, sivil toplum kuruluşları (STK'lar) ve yerel halk ile görüşmeler gerçekleştirmiştir. Suriye kaynaklı göçle birlikte Türkiye üzerinde oluşan etkiye ilişkin genel bir sınıflandırmanın ardından, Suriyelilerin bulunduğu illerde yürütülen saha araştırmaları analiz edilmiştir. Çalışma sonucunda üç konu üzerinde durulmuştur. Birinci olarak; Suriye'deki mevcut durum çözüme kavuşursa, göçmenler ya ülkelerine geri dönüş yapacak ya da Türkiye'de kalma kararı verecektir. İkinci konu; Suriyelilere ilişkin uygulanan politikalar hakkında daha detaylı bir şekilde düşünülmesi gereğidir. Son olarak, gelen göçmenlerle bütünleşik bir uyum sürecinin başarıyla yönetildiği takdirde bu durumun ileriye dönük hem toplumsal hem de diğer alanlarda gelişime olumlu yansımaları olabileceği ifade edilmiştir. Aydın da (2016) Suriyeli göçmenlerin işgücü ücretlerinde düşüşe neden olduğunu ve kayıt dışı çalışmayı arttırdığını belirtmektedir. Suriyeli kadın göçmenlerin istihdam oranı oldukça düşük ve neredeyse büyük çoğunluğunun çalışmadığı ifade edilmektedir (Barın, 2015: 45). Suriyeli göçmenlerin yeteneklerine odaklı eğitim programları onların işgücü piyasasına entegrasyon sürecini kolaylaştıracaktır (İçduygu ve Diker, 2017). 


\section{Bağlam}

Düzensiz olma durumu ile yasadışılık, göçmenlik açısından sosyo-politik inşa sürecinin sonucu olarak nitelendirilmektedir (Rittersberger-Tılıç, 2015). Bu araştırma, çalışma hayatı uluslararası düzensiz göçle karşılaştığında ortaya çıkan durumu betimlemeyi amaçlanmaktadır. Devam eden bölümde detaylı bir şekilde irdelenecek temalar ancak bağlamla ilişkilendirildiğinde doğru bir şekilde anlaşılabilecektir. Bu nedenle çalışmanın bu bölümü, araştırmanın yürütüldüğü bağlamın demografik, ekonomik ve sosyal özelliklerinin detaylı bir şekilde betimlenmesine ayrılmıştır.

\section{1. Şanlıurfa'nın Demografik ve Sosyo-ekonomik Durumu}

Şanlıurfa farklı kültür ve etnik kökenden birçok insanın yaşadığı bir ildir. Genel olarak konuşulan 3 dil; Türkçe, Kürtçe ve Arapça'dır. Güneydoğu Anadolu Bölgesi'nde bulunan Şanlıurfa ili, coğrafi açıdan Gaziantep'ten sonra bölgenin en büyük ilidir. Arazi yapısının dağlık olmaması büyük toprak mülkiyetlerinin ortaya çıkmasına sebep olmuştur. Şanlıurfa ilinin ekonomisi genel olarak tarıma dayalıdır (TÜik, 2014'ten aktaran, Lordoğlu ve Aslan 2016: 801).

Şanlıurfa'nın demografik yapısı içerisindeki genç nüfus oranının yüksekliği dikkat çekicidir. Öyle ki, 2013 yılı istatistikleri göz önüne alındığında doğum oranının yüksekliği azımsanamayacak kadar yüksektir. Türkiye'nin toplam doğurganlık hızı 2,07(çocuk) olmasına karşın Şanlıurfa da bu sayı 4,31'dir. Şanlıurfa bu istatistikle doğurganlık hızı açısından Türkiye'de ilk sırada yer almaktadır. 2013 yılı verilerine göre il nüfusunun \%61,03'ü 25 yaş altındadır. Türkiye 2013 yıllık nüfus artış oranı \%॰13,7 iken Şanlıurfa'da bu oran, \%o22,4'tür. Şanlıurfa ili ekonomisin in büyük bir bölümünü oluşturan tarımın dışında enerji, turizm ve hayvancılıkta da önemli bir yere sahiptir. Türkiye'nin en önemli bölgesel kalkınma projelerinden biri olan Güneydoğu Anadolu Projesi'nin (GAP) merkezi konumunda yer almaktadır. Türkiye'nin en büyük tarım çiftliği işletmesi olan Ceylanpınar Tarım İşletmeleri Şanlıurfa ilindedir. Şanlıurfa Atatürk Barajı da bu ilde bulunmaktadır. Ülkenin enerji ihtiyacının önemli bir kısmı Atatürk Barajı'nın hidroelektrik santrallerinden sağlanmaktadır (TÜIK, 2014: 12-13).

\section{2. Şanlıurfa'da Göç ve Etkisi}

TÜik (2016) verilerine göre Şanlıurfa il nüfusu: 1.940 .627 'dir. Suriye krizinden önceki nüfusu (2010) ise 1.663.371'dir. Sınır illerinde yaşanan göç hareketi ekonomik, demografik ve toplumsal alanda çeşitli sonuçlar doğurmuş ve beraberinde birçok sorunun ortaya çıkmasına neden olmuştur. Türkiye'de yaşanan göçten en çok etkilenen iller arasında Şanlıurfa önde gelmektedir. Şanlıurfa GiGM’ne (2016) göre 400 bin 967 Suriyeli göçmenle Suriyeli göçmen nüfusunun en yoğun yaşadığı il olarak ifade edilmektedir. Ayrıca Şanlıurfa - Diyarbakır (TRC2) bölgesi göç nedeniyle işsizlik oranındaki artışın en yoğun yaşandığı istatistiki bölge olarak karşımıza çıkmaktadır (Bahçekapılı ve Çetin, 2015: 8).

Göçmenlerin sınırı geçtikten sonra da Şanlıurfa'da kalmalarının çeşitli sebepleri vardır. Bu sebeplerden belki de en önemlisi akrabalık bağlarıdır. Şanlıurfa ilinin etnik köken bakımından çoğunluğunu Arap ve Kürtlerin oluşturması da bir başka önemli etkendir. Şehrin bu özelliği, göçmenleri dil ve kültür açısından zorlamayan ve bir arada yaşamayı kolaylaştıran bir etki yaratmaktadır. Şanlıurfa iline bağıı bazı ilçelerde (Mürşit Pınar, Akçakale ve Ceylanpınar) sınır kapılarının olması da bir başka önemli etkendir. Bunlara ek olarak aşiret ilişkileri ve ekonomik gelirin çoğunluğunun tarıma dayalı oluşu, psikolojik olarak göç edilen yere yakın olmanın sağladığı dönebilme umudu da Şanlıurfa iline göç edenlerin sayısında ve kalma sürelerinde belirleyici diğer etkenler olarak düşünülebilir. 
Şanlıurfa'daki kalkınma ve ekonomik gelişmenin görece düşüklüğü Suriye kaynaklı göçten daha yoğun bir şekilde etkilenmesi sonucunu doğurmaktadır. Şanlıurfa ili ortaya çıkan olumsuzlukları düzeltebilecek potansiyele henüz sahip değildir. Bu durum da sorunların giderek büyümesine neden olmaktadır. Daha önce ifade edildiği gibi Şanlıurfa'nın Suriye ile coğrafi yakınlığı, ekonomik gelişmişlik düzeyinin istenilen seviyede olmaması ve şehir nüfusunun yüksekliği yaşanan göç hareketinden olumsuz bir şekilde etkilenmesine neden olmaktadır (Pınar vd., 2016: 34).

\section{Yöntem}

Bu çalışma durum çalışma olarak tasarlanmıştır. Nitel araştırma gelenekleri arasında önemli bir yere sahip olan durum çalışmasına ilişkin farklı tanımlar bulunmaktadır. Örneğin bir tanıma göre durum çalışması; çoklu bilgi kaynakları, bir başka deyişle görüşme, gözlem, görsel-işitsel materyaller, dokümanlar ve raporlar kullanılarak gerçek yaşam veya güncel bir durum hakkında detaylı ve derinlemesine inceleme yapılıp bilgilerin toplandığı, durum ya da durumların betimlenmesidir (Creswell, 2013: 97). Bir başka tanımda durum çalışması; bir birey, grup, kurum veya toplum gibi sosyal bir birimin veya bir olgunun yoğun bir şekilde betimlenmesi ve analiz edilmesidir (Merriam, 2002: 8). Durum çalışması denildiğinde en çok akla gelen yazarlardan birisi olan Robert K. Yin'e (2003: 13) göre durum çalışması; güncel bir olgunun kendi doğal bağlamında incelendiği ve özellikle de olgu ve içinde bulunduğu bağlam arasındaki sınırların net bir şekilde belirlenemediği durumlar için uygun olduğu belirtilen görgül bir araştırma yöntemidir.

Bu çalışmada da durum çalışması geleneğiyle uyumlu bir şekilde araştırılan konu görüşmelerin yanı sıra çoklu bilgi kaynakları; görsel-işitsel materyaller, araştırma raporları ve resmî kurumlardan alınan istatistiklerle desteklenerek betimlenmiştir. Çalışma, Suriye kaynaklı göçün etkisiyle çalışma hayatında ortaya çıkan durumu zengin bir şekilde betimlemeyi amaçlamaktadır. Söz konusu durumun çalışıldığı yer Şanlıurfa ilidir. Şanlıurfa seçimi amaçlı olarak seçilmiş bir bağlamdır. Şanlıurfa pek çok açıdan göç ile çalışma hayatı ilişkisinin incelenmesini olanaklı kılmaktadır. Öncelikle Şanlıurfa göçten en çok etkilenen illerden birisidir. Göçün yaşandığı sınır bölgesinde yer almaktadır. Ayrıca Şanlıurfa Suriye ile kültürel ve sosyal bağların güçlü olduğu bir demografik yapıya sahiptir. Çalışmanın ikinci yazarının erişim kolaylığı ve konuşulan dillere olan hakimiyeti de Şanlıurfa seçimini öne çıkartan özellikler arasındadır. Çalışma kapsamında Şanlıurfa iline ilişkin özellikler bağlam başlığı altında detaylandırılarak durumun bağlamla ilişkili olarak anlamlandırılması olanaklı kılınmıştır.

\subsection{Katılımcıların Seçimi}

Bu çalışmada katılımcılar da amaçlı olarak seçilmiş ve araştırma konusunun etraflıca anlaşılabilmesi için maksimum çeşitliliğe izin verecek bir yaklaşım izlenmiştir. Bu seçim sürecinde amaç, probleme taraf olan katılımcıların çeşitliliğini yansıtmaktır. Bu yol, araştırma sürecinde incelenen olguya ilişkin derinlemesine inceleme imkânı sağlamanın yanı sıra, farkı boyutların ortaya çıkarıımasını da olanaklı kılmaktadır (Yıldırım ve Şimşek, 2016: 119). Seçilen farkı katılımcılarla yapılan görüşmeler, etkileşim içerisindeki bağlantıların bulunmasına imkân tanımaktadır. Çalışma kapsamında Şanlıurfa'daki Suriyeli göçmen çalışanlara, Suriyeli göçmen girişimcilere ve Suriyeli göçmen istihdam eden yerli işletmecilere odaklanılmıştır. Araştırma sürecinde görüşülen katılımcılar;

- 16 Suriyeli göçmen çalışan,

- 13 Suriyeli göçmen istihdam eden yerli işletme sahibi

- 11 Suriyeli göçmen girişimci olmak üzere toplam 40 kişiden oluşmaktadır. 
Görüşme kapsamında her katılımcının, araştırmada hazırlanan "Katılımcı İzin Formu”nu okuması, okuyamadığı durumlarda tercüme edilerek konunun anlatılması sağlanmıştır. Sözlü ve yazılı izin alındıktan sonra görüşme aşamasına geçilmiştir. Katılımcılara isimlerinin gizli tutulacağı bilgisi verilmiş ve bu nedenle katılımcılar kendi gruplarına uygun kısa takma adlarla etiketlenmiştir. (Bkz. Tablo 1. 2. ve 3.). Suriyeli Göçmen Çalışan grubundaki katılımcılar "SGÇ" şeklinde, Suriyeli Göçmen Girişimciler "SGG" şeklinde, Göçmen İstihdam Eden İ̧̧letme Sahipleri ise "Giis" şeklinde ifade edilmiştir.

\section{Tablo 1: Görüşme Yapılan Suriyeli Göçmen Girişimciler}

\begin{tabular}{lllll}
\hline İsim & Cinsiyet & Yaş & Eğitim Durumu & Meslek \\
\hline \hline SGG 1 & Erkek & 55 & -Yok- & Market \\
SGG 2 & Erkek & 38 & Lise Terk & Mobilya \\
SGG 3 & Erkek & 48 & Üniversite Mezunu & Market \\
SGG4 & Erkek & 44 & Lise Terk & Hazır Giyim \\
SGG 5 & Erkek & 24 & Üniversite Terk & Nargile \\
SGG 6 & Erkek & 28 & Lise Mezunu & Market \\
SGG 7 & Erkek & 22 & Ortaokul & Lokanta \\
SGG 8 & Erkek & 51 & Üniversite Terk & Market \\
SGG 9 & Erkek & 47 & Lise Terk & Kasap \\
SGG 10 & Erkek & 30 & Illköğretim & Kuyumcu \\
SGG 11 & Erkek & 34 & Ortaokul & Kozmetik \\
\hline
\end{tabular}

Tablo 2: Görüşme Yapılan Suriyeli Göçmen İstihdam Eden Işsletme Sahipleri

\begin{tabular}{lll}
\hline İsim & Cinsiyet & Meslek \\
\hline \hline GiiS 1 & Erkek & Kuaför \\
GiiS 2 & Erkek & Giyim Mağazası \\
GiiS 3 & Erkek & Kömürcülük \\
GiiS 4 & Erkek & Mısır Fabrikası \\
GiiS 5 & Erkek & Et Şarküteri \\
GiiS 6 & Erkek & Alışveriş Merkezi \\
GiiS 7 & Erkek & Zücaciye \\
GiiS 8 & Erkek & Kuyumcu \\
GiiS 9 & Erkek & Unlu Mamulleri \\
GiiS 10 & Erkek & Hurdacılık \\
GiiS 11 & Kadın & Giyim Mağazası \\
GiiS 12 & Erkek & Giyim Mağazası \\
GiiS 13 & Erkek & Lokanta \\
\hline
\end{tabular}

Tablo 3: Görüşme Yapılan Suriyeli Göçmen Çalışanlar

\begin{tabular}{lllll}
\hline İsim & Cinsiyet & Yaş & Eğitim Durumu & Meslek \\
\hline \hline SGÇ 1 & Erkek & 18 & Lise Terk & Kuaför \\
SGÇ 2 & Erkek & 18 & Lise Terk & Fotoğrafçı \\
SGÇ 3 & Erkek & 24 & Üniversite Terk & Garson \\
SGÇ 4 & Erkek & 33 & Üniversite Terk & Avm-Reyon Görevlisi \\
SGÇ 5 & Erkek & 41 & Lise Terk & Avm-Et Şarküteri Görevlisi \\
SGÇ 6 & Erkek & 36 & Illkokul Mezunu & Hurdacılık \\
SGÇ 7 & Kadın & 26 & Lise Terk & Giyim-Satıs Danışmanı \\
SGÇ 8 & Kadın & 20 & Lise Terk & Giyim-Satış Danışmanı \\
SGÇ 9 & Erkek & 34 & Lise Terk & İşaat \\
SGÇ 10 & Erkek & 15 & İlkokul & Giyim-Satış Danışmanı \\
SGÇ 11 & Kadın & 16 & ilkokul & Giyim-Satış Danışmanı \\
SGÇ 12 & Erkek & 20 & Ortaokul & Giyim-Satıs Danışmanı \\
SGÇ 13 & Erkek & 24 & ilkokul & Fabrika Çalışanı \\
SGÇ 14 & Erkek & 42 & Ortaokul & Kozmetik Satış Elemanı \\
SGÇ 15 & Erkek & 29 & Ortaokul & İnşaat \\
SGÇ 16 & Erkek & 37 & Ortaokul & İşaat \\
\hline
\end{tabular}




\subsection{Veri Elde Etme Aracı ve Verilerin Analizi}

Görüşme için izin istenilen 3 grup ile birbirinden farklı şekilde alanyazınla ilişkilendirilerek hazırlanan yarı-yapılandırılmış görüşme soru formları ile görüşmeler yapılmıştır. Görüşmelerde katılımcıların ses kayıtları da alınarak çalışma hayatı uluslararası düzensiz göçle karşılaştığında ortaya çıkan durum derinlemesine araştırılmıştır. Yarı-yapılandırılmış görüşmelerde araştırmacı tam anlamıyla düzenlenmiş bir yol haritasına sahip değildir. Cevaplayan kişiye, konunun akışına göre çalışmanın genel çerçevesi dışında farklı sorular sorabilmektedir. Bu sorular araştırmayı amacından saptırmayan ve konunun değişik boyutlarını ortaya çıkarmaya yöneliktir. Böylece araştırma yapan kişiye hem bilgiye çok yönlü ulaşma hem de mülakatı belli bir seyirde götürme imkânı sunmaktadır (Coşkun vd. 2015: 94-95). Çalışma kapsamında yürütülen görüşmelerden elde edilen ses kayıtları deşifre edilmiş ve 15 sayfalık bir görgül materyal elde edilmiştir. Ses kaydı yapılamayan durumlarda ise görüşmeci detaylı bir şekilde not tutmuştur. Elde edilen tüm görgül materyal betimsel olarak analiz edilerek çalışma kapsamındaki bulgulara ulaşılmıştır. Betimleme, toplanan verilerin hangi temalara odaklandığıyla ilgilidir. Analiz sürecinde veri doygunluğu önemli bir aşamadır. Her ne kadar veri doygunluğuna ilişkin net bir tanım olmasa da kavramın araştırmaçını sorguladığı konuya ilişkin yeni ifadelerle karşılaşmıyor olması anlamına geldiği bilinmektedir. Bu çalışmanın analiz sürecinde de benzer kodların tekrarlı bir şekilde ortaya çıkmaya başlaması kodların belli bir kalıp içerisinde temalaştırılması sonucunu doğurmuştur. Temalaştırma sürecinde yürütülen görüşme sayısı Guest vd. (2006) tarafından önerilen sayısal aralıkla tutarlılık göstermektedir.

Veriler betimsel olarak analiz edilmiştir. Betimsel analiz; görüşülen ya da gözlenen bireylerin düşüncelerini yansıtmak, doğrudan alıntılara sık sık yer vermek ve görüşme sonrasında katılımcılardan elde edilen veriler ışığında yorumlama yapabilmektir. Açıklamalar ve düzenlemelerle konuyla bağlantılı olarak neden-sonuç ilişkisi kurulur ve ortaya çıkan sonuçlar anlamlandırılır (Yıldırım ve Şimşek, 2016: 240-241). Son olarak, betimsel analize dayalı nitel paradigma ışığında yürütülen bu çalışmada geçerlilik ve güvenilirlik konusunun bütüncül bir şekilde Lincoln ve Guba (1985) tarafından önerilen inandırııılık kavramıyla ilişkilendirildiği belirtilmelidir. Bu kapsamda araştırmacının inandırıcılığı, transfer edilebilirlik, güvenilmeye layık olma ve onaylanabilirlik şeklinde ifade edilen inandırıcılığın temel boyutları (Guba, 1981) göz önünde bulundurulmuştur. Çalışmanın görgül materyalinin analiz edilmesi sonucunda, kodlara ilişkin örnek alıntıların görüldüğü Tablo 4'te özetlenen tematik örüntüye ulaşılmıştır. 
Ağustos 2019, C. 14, S. 2

Tablo 4: Veri Çözümlemesinde Belirlenen Temalar ve Kodlar

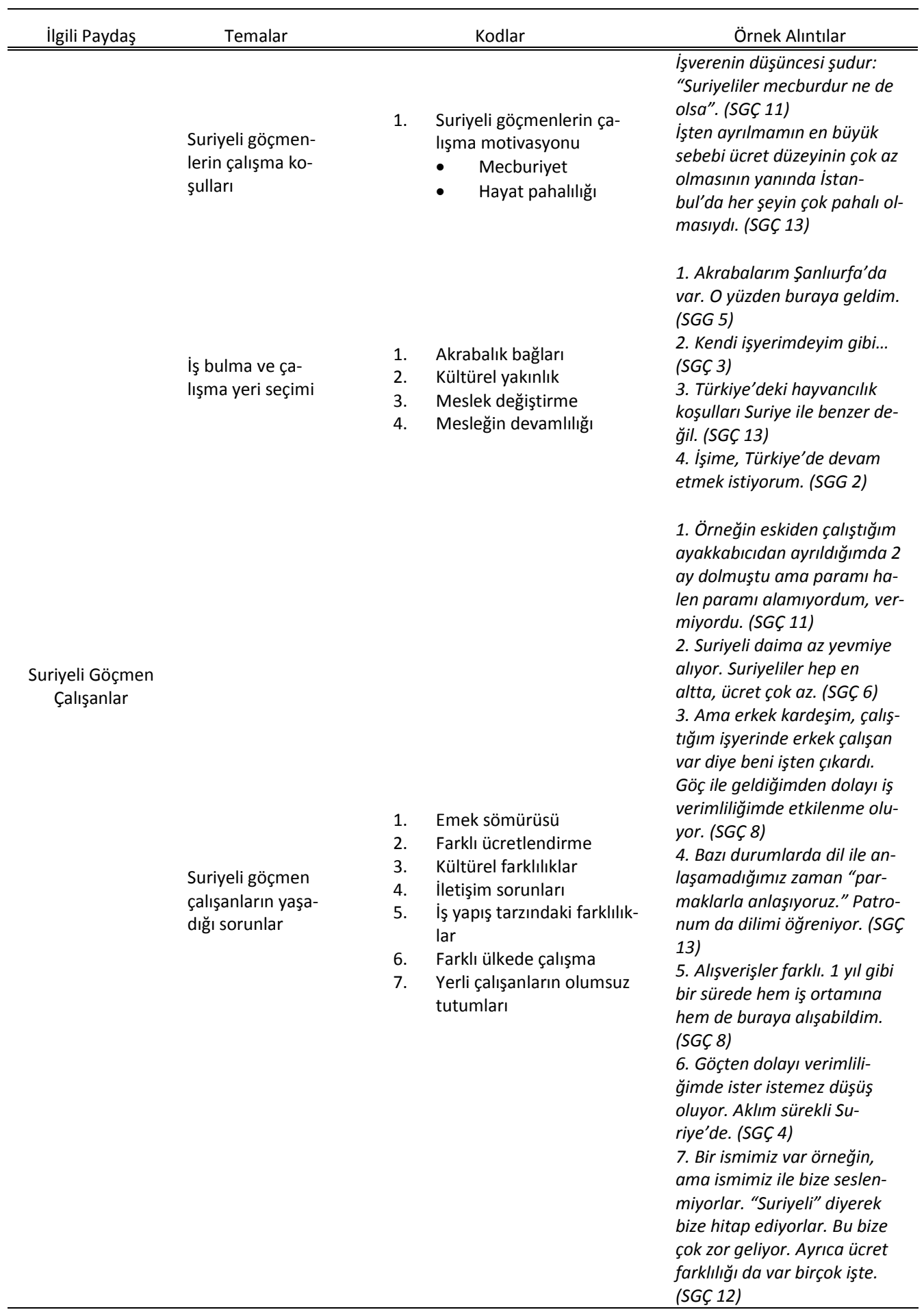




\begin{tabular}{|c|c|c|c|}
\hline $\begin{array}{l}\text { Suriyeli Göçmen } \\
\text { İstihdam Eden } \\
\text { İşletme Sahipleri }\end{array}$ & $\begin{array}{l}\text { Suriyeli göçmen } \\
\text { istihdamı }\end{array}$ & $\begin{array}{ll}\text { 1. Mesleki tecrübe } \\
\text { 2. Destek olmak amaçlı istih- } \\
\text { dam } \\
\text { 3. Müşteri çekme potansiyeli } \\
\text { 4. Yabancı dil bilgisi } \\
\text { 5. Yerli işçi istihdamında yaşa- } \\
\\
\text { nan sorunlar }\end{array}$ & $\begin{array}{l}\text { 1. Bilgi lazım. Tecrübe lazım. } \\
\text { Bizde ayrımcılık yok. Kim işini } \\
\text { doğru düzgün yaparsa onu } \\
\text { işe alırım. (Giis 1) } \\
\text { 2. Suriyelileri pek tercih et- } \\
\text { mem fakat durumu olmayan- } \\
\text { lara destek olabilmek için dü- } \\
\text { rüst Suriyelileri işe alıyorum. } \\
\text { (Giis 2) } \\
\text { 3. Suriyelilerin işletmeme } \\
\text { olan olumlu etkisi, kendileri } \\
\text { gibi olan Suriyeli müşterileri } \\
\text { de beraberinde getirmeleri- } \\
\text { dir. Yani işlerim daha bir can- } \\
\text { lılık kazanıyor. (Giis 7) } \\
\text { 4. Dil konusunda tecrübeliler. } \\
\text { Dilimizi bilen birisi olduğu için } \\
\text { anlaşıyoruz. (Giis 8) } \\
\text { 5. Çünkü yerli işçiler bu işi } \\
\text { yapmıyor. Suriyeliye verdiği- } \\
\text { miz ücreti yerli kabul etmedi. } \\
\text { işimi yapamadılar. (Giis 10) }\end{array}$ \\
\hline \multirow{3}{*}{$\begin{array}{l}\text { Suriyeli Göçmen } \\
\text { Girişimciler }\end{array}$} & $\begin{array}{l}\text { Suriyeli göçmen- } \\
\text { leri girişimci ol- } \\
\text { maya iten sebep- } \\
\text { ler }\end{array}$ & $\begin{array}{l}\text { 1. Ağır çalışma koşulları ve } \\
\text { hakkını alamama }\end{array}$ & $\begin{array}{l}\text { 1. Tam } 13 \text { saat çalışıyordum. } \\
\text { Aldığım ücret ise } 1.000 \text { TL idi. } \\
\text { istanbul'da hayat pahalı. Ge- } \\
\text { çimimi sağlamak için kendi iş- } \\
\text { letmemi açmak istedim. (SGG } \\
\text { 5) }\end{array}$ \\
\hline & $\begin{array}{l}\text { Kuruluş yeri se- } \\
\text { çimi }\end{array}$ & $\begin{array}{l}\text { 1. Suriyelilerin yoğunlukta ol- } \\
\text { duğu yerler } \\
\text { 2. Coğrafi yakınlık }\end{array}$ & $\begin{array}{l}\text { 1. Yaptığım iş hem Suriyeli- } \\
\text { lere hem de yerlilere hitap et- } \\
\text { mektedir. Müşterilerimizin } \\
\text { çoğu Suriyelidir. (SGG 5) } \\
\text { 2. Markete gelen müşterileri- } \\
\text { min hemen hemen hepsi Suri- } \\
\text { yelilerden oluşmaktadır. (SGG } \\
\text { 3) }\end{array}$ \\
\hline & $\begin{array}{l}\text { Suriyeli göçmen } \\
\text { girişimcilerin ya- } \\
\text { şadığı zorluklar }\end{array}$ & $\begin{array}{l}\text { 1. İşyeri açma sürecinde yaşa- } \\
\text { nan zorluklar } \\
\text { 2. Tedarik süreçleriyle ilgili ya- } \\
\text { şanan sorunlar }\end{array}$ & $\begin{array}{l}\text { 1. IFakat zamanla benim } \\
\text { müşterilerim çoğalınca diğer } \\
\text { komşu giyimcilerin zoruna } \\
\text { gitti ve beni tehdit ettiler. } \\
\text { (SGG 4) } \\
\text { 2. Fakat yılbaşından sonra } \\
\text { Şanlıurfa dışına, yani işyeri- } \\
\text { mizin bağlı olduğu il dışına çı- } \\
\text { kılması için birçok belgenin } \\
\text { hazırlanması zorunlu kılındı. } \\
\text { (SGG 5) }\end{array}$ \\
\hline
\end{tabular}




\section{Bulgular ve Yorum}

Çalışmanın bu bölümünde yürütülen betimsel analizle koşut olarak öncelikle Suriyeli göçmenler, daha sonra Suriyeli göçmen istihdam eden işletme sahipleri ve son olarak da Suriyeli göçmen girişimcilerin durumları çalışma hayatı bağlamında doğrudan alıntılar yardımıyla etraflıca betimlenmeye çalışılacak, ortaya çıkan duruma ilişkin kodlar ve bütüncül temalar paylaşılacaktır.

\subsection{Suriyeli Göçmenlerin Çalışma Koşulları}

\subsubsection{Suriyeli Göçmenlerin Çalışma Motivasyonu}

\subsubsection{Mecburiyet}

Yaşları küçük olmasına rağmen, çalışmak zorunda olduklarını belirten Suriyeli göçmenler, bu durumu "mecburiyet" olarak tanımlamaktadır. İşletmeden işletmeye değişmekle beraber, yerli bir işçiye verilen ücret ile kendisine verilen ücret arasındaki farka dikkat çeken Suriyeli çaIışan, kendilerine yönelik "Suriyeliler, mecbur ne de olsa" gibi olumsuz bir tutumun varlığından söz etmekte ve bu durumun kendilerini psikolojik açıdan rahatsız ettiğini ifade etmektedir. Ücretlerin düşüklüğüne ek olarak bazen çok geç, bazen de hiç ödenmemesi Suriyeli çalışanların belirttiği sorunlar arasındadır.

Suriye'de mecburiyet yok. Türkiye'de çalışma mecburiyeti var. Ben buradaki yerli işçilerle aynı parayı almıyorum. Örneğin ben haftalık 140 alıyorum. Diğer arkadaşlarım 160 alan var, 180 alan var, 200 alan var. İ̧̧verenin düşüncesi şudur: "Suriyeliler mecburdur ne de olsa". (SGÇ 11)

\subsubsection{Hayat Pahalılığı}

Suriyeli göçmen, Şanlıurfa'ya göç etmesinin nedenini akrabalık bağlarıyla ilişkilendirmekte, daha önce çalıştığı şehirdeki işyerinden ayrılmasının sebebinin ise "hayat pahalılı̆ı" olduğunu belirtmektedir. Düşük ücretle ağır işlerde çalışmalarına rağmen, başka şehirlerden göç etme durumunun sadece iş odaklı olmadığı görülmektedir. Bu durumu etkileyen nedenler arasında; akrabalık bağları, şehirler arası yaşam düzeyi, bir başka ifadeyle hayat pahalılığı, işverenin yaklaşımı gibi sebepler bulunmaktadır. Bir bütün olarak değerlendirildiğinde Suriyeli göçmenler için; adil ücret düzeyi, olumlu tutum ve yaklaşım, çalışma koşulları ve akrabalık bağları, işletmelerde çalışabilmenin ve sürekliliğin birer ölçütü olarak kabul edilmektedir.

inşaattan başka lokantada da çalıştım. Çalıştığım lokanta Antalya'daydı. Benim akrabalarım Şanlıurfa'da olduğu için ve Şanlıurfa Antalya'ya göre pahalılık açısından daha uygun bir yer olduğu için buraya geldim. (SGÇ 9)

Şehirlerdeki farklılıklar, hayat pahalılı̆̆ ve diğer yaşam koşulları da çalışan kişiyi derinden etkileme gücüne sahip olabilmektedir.

\subsection{2. İş Bulma ve Çalışma Yeri Seçimi}

\subsubsection{Akrabalık Bağları}

Türkiye'ye geliş sebeplerini; akrabalık bağlarına dayandıran Suriyeli göçmenler hayatlarını Şanlıurfa'da sürdürmek ve çalışmalarına da burada devam etmek istediklerini belirtmişlerdir.

Işsime, Türkiye'de devam etmek istiyorum. Türkiye hem rahat ve hem de burada akrabalarımız var. Memnunuz. (SGG 2)

Şanlıurfa'da kalmak istiyorum. Hem akrabalarım burada hem de Suriye'ye gitmek istemiyorum. (SGG 4) 
Akrabalarımın çoğu burada. O yüzden buraya geldim. (SGÇ 6)

Akrabalarımızın çoğunun daha önceden Şanlıurfa'da oluşu, bizim de buraya gelişimize vesile oldu. Şanlıurfa'da market işletiyorum. Bütün eşyalarımızı Şanlıurfa'dan temin ediyoruz. Genel olarak Suriyeli müşterilerimiz daha yoğunluktadır. (SGG 6)

Daha önce, bu şimdi çalıştığım işten başka, inşaatlarda çalıştım. Antalya'da meyve ve sebze halinde çalıştım 1,5 yıl boyunca. Ve 2 yıldır da burada giyim mağazasında çalışıyorum. Yani ben çok iş yaptım. Şanlıurfa'da hem akrabalarım hem de babam burada. (SGÇ 12)

\subsubsection{Kültürel Yakınlık}

Sınırların birbirine olan yakınlığı, örf adet benzerliği, konuşulan dillerin benzerliği ve güçlü bir geçmiş bağlantının olması, özellikle Türkiye'nin sınır illeri ile Suriye arasındaki kültürel ilişkilerin devam ettiğini göstermektedir. Öyle ki Türkiye'ye gelen Suriyelilerin çoğu sınır illerinde fazla uyum sorunu yaşamadan hayatlarını sürdürmektedir. Kültürel yakınlığın varlığı ticari ilişkilere de yansımaktadır. Örneğin, sınır illerinde gıda sektöründe bu durum kendisini göstermektedir. Suriye'de içilen çay ile sınır illerinin çoğunda içilen çay daha çok bilinen adıyla "kaçak çay" aynıdır.

Çalışanlarımız hem Suriyeli hem de yerli olabilir. Çünkü birbirimizin zevklerini anlayabiliyoruz ve dil konusunda anlaşabiliyoruz. (SGG 2)

\subsubsection{Meslek Değiştirme}

Göç edilen ülkede yapılan işlerin menşe ülkeye göre farklı olması meslek değişimlerine neden olabilmektedir. Suriye'de iken hayvancılık işiyle uğraşan katılımcı, hayvancılık işine ilişkin koşuların farklı olmasından dolayı bu işi Türkiye'de devam ettirememiştir.

Şu an mısır fabrikasında çalışıyorum. Mısır kurutmada kömür işiyle ilgileniyorum. Suriye'de iken hayvancılık işiyle uğraşıyordum. Türkiye'deki hayvancılık koşulları Suriye ile benzer değil. (SGÇ 13)

\subsubsection{Mesleğin Devamlılığı}

Suriye'de iken yaptığı iş ile Türkiye'de yaptığı iş aynı olan Suriyeli işletmecinin müşterileri, genellikle Suriyelilerden oluşmaktadır. Birbirlerinin zevk ve ihtiyaçlarını daha çok anladıklarını belirten katılımcı, dil konusunda da müşterilerine yardımcı olduklarını belirtmiştir.

Müşterilerimiz genellikle Suriyelidir. Çünkü birbirimizin zevklerini anlayabiliyoruz ve dil konusunda anlaşabiliyoruz. İşime, Türkiye'de devam etmek istiyorum. (SGG 2)

\subsubsection{Suriyeli Göçmen Çalışanların Yaşadığı Sorunlar}

\subsubsection{Emek Sömürüsü}

İşe başlama ve işin bitiş saatlerinin belli olmaması ile işverenlerin verdikleri ücretin düşük olması işten ayrılma sebepleri arasında gösterilmiştir. Yaşanan bu sorunlar, iş bırakmayı tetiklemektedir. Sonraki işlerde göçmen ve yerli çalışanlar arasında ücret düzeyinin farklı olmamasının ve işçiler arasında ayrımcılığın daha az olmasının işyerine ve işverene olan bağlılı̆ı arttırdığı belirtilmiştir.

Ayakkabı mağazasındaki işverenim ile bundan dolayı sorunlar yaşadım. Yerli iş̧̧iye 60 $T L$, bana ise $40 T L$ veriyordu. Onu eve erken gönderiyordu beni ise eve geç gönderiyordu. Bazen gece 23.00'e kadar çalıştığım zamanlar oluyordu. Şu anki işim iyi. Ayrımcılık yok ve ustamın yaklaşımı iyidir. (SGÇ 1) 
Daha önceden simit satışı yapan bir yerde 2 yıl çalıştım. Ve yine bir ayakkabıcının yanında çalıştım 6 ay boyunca. Bu işlerden ayrılmamın sebebi hem ücretin düşük verilmesi hem de paramızın geç verilmesiydi. Yani biz istemesek paramızı vermezdi. Zamanında da vermezdi. Örneğin eskiden çalıştığım ayakkabıcıdan ayrıldı̆̆ımda 2 ay dolmuştu ama halen paramı alamıyordum, vermiyordu. (SGÇ 11)

\subsubsection{Farklı Ücretlendirme}

Yapılan görüşmelerde aynı işyerinde çalışan ve aynı işi yapan göçmen ve yerli çalışanlar arasında, ücret açısından farklılık olduğuna işaret edilmiştir. Haftanın yarısını işyeri dışındaki çalışmalarla geçiren katılımcı emeklerinin karşılığını alamamakla beraber yaptığı işi başkasına öğretmesinin talep edildiğini dile getirmektedir. Bu durum işletme içindeki sorunların giderek büyümesini ve işten ayrılmaların ortaya çıkmasına neden olmaktadır.

Bize az para veriliyor. Hakkım olanı alamıyorum. Burada aldığım ücret bana yetmiyor. Kontörlerime bile yetmiyor. Haftalık 80 TL alıyorum... Ücret farklılı̆ı vardı. Ayrımcılık vardı. Mesela fotoğrafçılık konusunda deneyimi olmayan yerli işçiye haftalık $130 \mathrm{TL}$, bana ise deneyimli olmama rağmen haftalık $80 \mathrm{TL}$ verdiler. Ona da bir şey demedim. Fakat benim işten ayrılmamın esas sebebi, ücret farklılığı olmasına rağmen bana: "arta kalan zamanlarda yerli iş̧̧iye bildiklerini de öğret" demeleridir. Zaten ücret az ve kendi işimi yapıyorum. Bir de başka birine öğretip ondan düşük ücret almam zoruma gitti. (SGÇ 2)

İşverenler maliyet kısıtlarını öne çıkarttıkları görüşmelerde Suriyeli göçmenlerin düşük ücretle çalışmayı kabul ettiklerinden (mecbur olduklarından) işletmelerde kendilerine iş bulabildiklerini belirtmektedir.

Birçok Suriyeli gelip yanımda çalışıyor. Suriyeli göçmenleri diğerlerine göre tercih etmemin sebebi iş̧̧iliklerinin ucuza mal olmasıdır. Masraflarımız ağırdır. O yüzden dolayı ileride de Suriyelileri düşük iş̧̧ilikleri için istihdam etmeye devam etmek isterim. Kiralar pahalı, maliyetler pahalı... (Giis 7)

Yerli iş̧̧i pahalıya geliyor. Suriyeli işçi \%50 daha kârlı bizim için. Suriyeli işçileri çalıştırdıktan sonra işletmemizde olumlu etki olarak, fiyat açısından uygun olduğu için bize artı değer kattı. (Giis 4)

\subsubsection{Kültürel Farklılıklar}

Kültürel farklılıkların, işletme içi faaliyetleri derinden etkileme potansiyeline sahip olduğunu söyleyebiliriz. Ülkeler arasındaki kültür farklılıkları kendini sadece günlük yaşamda göstermemektedir. İş ortamındaki bazı uygulamaların değişiklik göstermesi kültürel farklılıkların iş yaşamına yansıması olarak ifade edilebilir. Görüşme yapılan Suriyeli göçmen çalışanın "bizde erkek personeller erkek müşterilerle, kadın personeller ise kadın müşterilerle ilgilenmektedir" şeklinde ifade ettiği durum göç edilen toplumdaki baskın eril kültürün oldukça net bir yansımasıdır. Görüşülen bir başka Suriyeli göçmen katılımcı, ülkeler arasındaki farklıığın sadece iş ortamında olmadığını hayatın her alanında bunun açıkça görüldüğünü, hatta "her şey de farklılık olduğunu" dile getirmektedir. Yeni işyerinde, daha önce çalıştığı iş olan giyim mağazasında çalışan Suriyeli göçmen işverenin onların farklılıklarına saygı gösterdiği için bu işte çalışabildiğini belirtmiştir.

Suriye iş ortamı ile Türkiye iş ortamı çok farklı. Her şey farklı. Alışverişler farklı. Daha önce de yine giyim işinde çalıştım. $O$ işten ayrılmamın sebebi, bir erkek işyerimize geldiğinde işveren bana: "Utanma! Onlarla iletişim kur. Müşterilere sıcak davran" diyordu. 
Bizim kültürümüzde erkek müşteriler ile erkekler, kadın müşteriler ile kadınlar ilgilenir. $O$ yüzden çıktım. Yani kültür farklılı̆ı var. (SGÇ 8)

Her ne kadar yakın coğrafyalardan söz ediyor olsak da kültürel farklılıklar, göç olgusunun taraflarınca uyum konusunda zorluk yaşanan alanlar arasında öne çıkmaktadır. Özellikle giyim ve gıda sektörlerinde çalışan göçmen katılımcılar, kültür farklılığın olumsuz etkilerini belirgin bir şekilde hissetmekte ve dile getirmektedir.

Şanlıurfa ile Suriye iş ortamı arasında farklılıklar vardır. Insanların giyim zevkleri de farklıdır. Uyum sorunu yaşıyorum. İşe alışmakta zorlandım. Göç verimliliği etkiliyor. Insanın kendi memleketinde çalışması ile başka bir yerde olması arasında çok fark var. (SGÇ 7)

\subsubsection{4. İletişim Sorunları}

İletişim, her görüşmede dile getirilen sorun kaynaklarındandır. İşletme içinde işlerin aksamadan zamanında yürümesi, örgüt içi iletişimin etkili bir şekilde sürdürülmesine bağlıdır. İletişim kaynaklı sorunlar aynı zamanda müşterilerin istek ve ihtiyaçlarına zamanında cevap verilmesini de güçleştirmektedir. İşveren ile işçi arasındaki iletişim sorunları zaman kaybına da neden olmaktadır. Bu kayıp hem müşteriye hem işverene olumsuz yansıyabilmektedir. Görüşme yapılan işletme sahibi, yanında çalışan Suriyeli göçmen çalışana yapması gereken işe ilişkin emir verirken, aynı cümleyi 3-4 kez tekrarlamak zorunda kaldığını söylemiştir.

İsyerime gelen müşterilerimin ihtiyaçlarına daha hızlı cevap verildiği zaman hem ben rahat ederim hem de müşterilerim memnun olur. İşi anladığı zaman yani bir işi onlara anlattığım zaman yapamadıklarında veya ufak bir görevi onlara verdiğimde yapamıyorlarsa bu konuda onlar da sıkıntı çekebilir. Suriyeli göçmen çalışanlarla iletişimde biraz sorun yaşıyoruz. Hani bazen konuşmalarımı anlamıyor. Bazen ben onun konuşmalarını fazla anlamıyorum. Yine de büyük sıkıntılar yaşamıyoruz onunla. Suriyeli çalışanların en çok zorlandığı konu, bir işi bir sorumluluğu ona yüklediğimde verdiğimde onu pek anlayamaması, 3 ya da 4 defa ona tekrar etmem ve sonradan onu anlaması. Bu da bana ciddi manada değil ama sıkıntı yaşatıyor. Zaman kaybı oluyor. (Giis 2)

Yaptıkları işin hem Suriyeli göçmenlere hem de yerlilere hitap ettiğini belirten Suriyeli girişimci, müşterilerin çoğunluğunu Suriyelilerden oluştuğunu ve yanlarında çalışan veya çalışacak olan kişilerin bu dili bilmelerinin şart olduğunu ifade etmektedir.

Yaptığım iş hem Suriyelilere hem yerlilere hitap ediyor. Müşterilerimin çoğunu Suriyeliler oluşturmaktadır. Yanımızda çalışan iş̧̧i Suriyelidir. Çünkü dilimizi biliyor. Dil olmazsa olmaz. Dilimiz Arapçadır. Ayrıca Türkçe ve Kürtçe dillerini de biliyor. (SGG 10)

Suriyelilerin en çok zorlandığı konu dildir. Dillerinde biraz sıkıntı yaşıyoruz. Konuşma esnasında aksamalar ve kopukluklar yaşanıyor. (Giis 8)

\subsubsection{5. İ̧̧ Yapış Tarzındaki Farklılıklar}

Yaşanılan ve çalışılan ortamın değişmesi çalışanın işletme içindeki işe uyum sürecini de etkilemektedir. Bu durum çalışanın işi anlaması ve gereklerini yerine getirmesi için sarf etmesi gereken çabanın artması ve daha fazla zaman harcaması sonucunu doğurmaktadır.

Göç ile geldiğimde ilk başta iş verimliliğimde etkilenme oldu. Aklım Suriye'de. Iş̧i daha önceden biliyordum ama işi bilmek ile iş ortamının değişmesi biraz beni zorladı. Bu iş ortamına değişmesi biraz beni zorladı. Bu iş ortamına alışmam biraz zaman aldı. Bu zaman 1 yılı buldu. (SGÇ 6) 
Suriye iş ortamı ile Türkiye iş ortamı arasında her şey değişiyor. İ̧̧lerin işleyişi, sistemi tamamen farklı. Ücretler de farklı. Örneğin, Suriye'de küçük çaplı inşaatlar hep var. Türkiye'de ise büyük inşaatlar var. Buradaki iş ortamına uyum sağlamam 3 aylık bir zaman aldı. Çünkü buranın sistemi ile Suriye'deki iş ortamı farklıdır. Her şehrin özelliği farklıdır. Inşaat aynı iş ama sistem farklı. Buradaki yerli iş̧̧iler ile biz elbette aynı olamıyoruz. Insanın kendi evinde çalışması ile bir yabancı ile çalışması arasında fark var. Bu bize yansıyor. (SGÇ 15)

\subsubsection{Farklı Bir Ülkede Çalışma}

Yapılan görüşmelerde göçün çalışanın işine ilişkin ve çalışmaya ilişkin algısı üzerinde olumsuz etkileri olabildiği saptanmıştır. İnsanın kendi evinden uzakta olması, ailesinden uzakta olması gibi cümlelerle durumu ifade eden Suriyeli göçmen katılımcı, psikolojik açıdan da bu durumdan olumsuz etkilendiğini dile getirmiştir.

Gö̧ olgusu, benim çalışma verimliliğimi etkiliyor. İster istemez etkiliyor. Kendi yaşadığım yerden uzak bir yerde çalışmaya başladım. Psikolojik olarak etkileniyorum. Annem ve babam yanımda değil. (SGÇ 3)

Göç ile geldiğim için çalışma verimliliğim etkileniyor. Aklım hep Suriye'de. (SGÇ 5)

Göç verimliliğimizi etkiliyor. Suriye'de daha faydalı olabilirdim işyerlerinde. Çünkü hem dil açısından zorlanıyorum hem de yabancılık çekiyorum. Suriye'deki insanlar bize karşı iyiydi. (SGÇ 12)

\subsubsection{Yerli Çalışanların Olumsuz Tutumları}

Belli bir süre boyunca Türkiye'den gelen yardımlarla yaşamlarını sürdüren Suriyeli göçmenler, sürenin uzamasından dolayı yavaş yavaş iş hayatına entegre olmaya başlamıştır. Böylesi bir durum en çok sınırda yaşayan yerli halkı endişelendirmiştir. İşletmelerde işgücü ücretlerini düşüren Suriyeli göçmenler, yerel halkın işsiz kalmasına sebebiyet verebilme riski taşımasından dolayı ciddi protestoların odak noktası haline gelmiştir (HÜGO, 2014: 27). Suriyeli göçmenlerin onur kırıcı sözlere maruz kalması onları oldukça üzmektedir. Çalışma koşulları iyi ve ücret düzeyi yeterli olsa bile yaşanan bu hoş olmayan durumun işten ayrılma sebebi olarak ifade edildiği görülmüştür.

Mesela seni tanıyan biri Suriyeli bile olsan nasıl bir kişiliğe sahip olduğunu bilir. Ama tanımayan biri hep önyargılı davranıyor. Suriyelilere yönelik olumsuz bir algı var. Ben burada çalıştığım zaman müşteriler bana: "acaba bu Suriyeli kimdir? nasıl biridir?" diyorlardı. (SGÇ 11)

Stres ve olumsuz düşünceler işimi tam yapmamı engelliyor. İ̧ yapıyorum ama moralim fazla yok. Bir de Suriyelilere yönelik hep kötü bir algı var. Neymiş, Suriyeliymişim kötü biriymişim. Bu algı yanlış. Her insan farklıdır. lyi insanda var kötü insan da. Genelleme yapılamaz. (SGÇ 8)

\subsection{Suriyeli Göçmen İstihdamı}

Suriyeli göçmenlerin ekonomik etkileri; fırsatları ve riskleri barındıran bütünleşik yapıdır. Suriyeli göçmenlerin varlığı, kira fiyatlarının yükselmesinden dolayı ev bulmayı zorlaştırmakta, özellikle sınır illerinde enflasyon oranlarını arttırmakta, işletmelerde çocuk işçiler ve kaçak işçiler çalıştırılmasına neden olmakta, kaçak göçmen çalıştıran ve çalıştırmayan işletmeler arasında 
haksız rekabet yaratmaktadır. Yerel halk göçmenlerin varlığından dolayı işsiz kaldığını ifade etmektedir. Ayrıca göçmen istihdamı, ücretlerde belirgin oranda düşüşe de sebep olmuştur (Oytun ve Şenyücel-Gündoğar, 2015: 8).

\subsubsection{Mesleki Tecrübe}

Çalışan bulma ve seçme süreçlerinde aranan özellikler "işten anlamak ve işi en iyi yapmaya çalışmak" şeklinde ifade edilmiştir. Nitelik gerektiren işlerde niteliksiz işgücü istihdam edilemeyeceğini belirten katılımcı, işinde deneyimli olan Suriyeli göçmenleri bulup seçtiğini belirtmektedir. İşletmede deneyim gerektiren işler için açık, nitelikli Suriyeli göçmen istihdam ederek kapatılmaya çalışılmaktadır.

Suriyeli göçmen çalışanların vasıfı olmasını herkes ister. Ister istemez bilgi ve tecrübe önemlidir. (Giis 6)

Suriyeli göçmenlerin tecrübeli olanlarını işe alıyorum. Vasıflı olanları, vasıfsız olanlara göre daha çok tercih ediyoruz. (Giis 9)

Tecrübeli olanları çalış̧ırıyorum. Onları işten çıkarmıyorum. Onların yerine başka birini bulup onları işe alıştırmak zamanımı alıyor. (Giis 7)

\subsubsection{Destek Olmak Amaçlı İstihdam}

İşverenler, Suriyeli göçmenleri bazı durumlarda niteliksiz olsa bile çalıştırdıklarını, bu durumun yardım etme veya destek olmak amaçlı vicdani bir karar olarak değerlendirmektedir.

Suriyelilere güveniyoruz. Çoğu zaman kasamızı bile onlara bırakıp dışarıya gönül rahatlığıyla gidebiliyoruz. Çünkü Suriyeliler çalışmaya mecbur. Niyetimiz Allah rızası içindir. Amacımız evlerine ekmek götürmelerini sağlamaktır. Vicdani bir karar yani. İslam penceresinden bakarak onları istihdam ettim. (Giis 6)

İşletmem içerisinde 5 yıldan beridir Suriyeli göçmen istihdam ediyorum. Suriyelileri istihdam etmemin en büyük nedeni onlara faydamı dokunsun diye. Kötülüklere alışmasın diye. Hırsızlık yapmasın diye. Amacımız onların bize ne kadar iyi insanlar demelerini ve bizim ülkemiz hakkındaki düşüncelerinin iyi yönde olmasını sağlamaktır. Biz onlara yardım etmek istiyoruz. (Giis 9)

\subsubsection{Müşteri Çekme Potansiyeli}

Suriyeli göçmenlerin yoğun olarak yaşadığı yerlerin varlığı, Suriyeli göçmen istihdamını tetikleyen bir başka önemli etkendir. Suriyeli göçmenlerin müşteri çekme potansiyeli işletme sahiplerinin gözünden kaçmamış ve bu durum bir fırsata dönüştürülmüştür.

Suriyelilerin işletmemize olumlu etkisi oldu. Öyle ki Suriyeli müşterilerimiz çoğaldı. Yani onlar müşterilerin işletmeye çekilmesine vesile oluyor. Çevresini getiriyor. Suriyeli göçmenleri 5 yıldır istihdam ediyorum. Alışveriş merkezimizde 2 Suriyeli çalışan bulunmaktadır. Bizim gibi Suriyeli istihdam eden işletmeler çoktur. Birçok Suriyeli kendi işini kurmuştur. Hatta bizler, Suriyelilerden mal alma durumuna gelmişiz. Suriyeli göçmenleri istihdam açısından diğerlerine göre tercih ederim. (Giis 6)

Arap bir müşteri geldiği zaman o müşteriyle Suriyeli çalışanlarım ilgilenir. Suriyelileri istihdam ettikten sonra işletmemde olumlu etkiler oldu. Örneğin; bir Arap müşterim geldiği zaman onlarla irtibata geçiyorlar. (Giis 12) 


\subsubsection{Yabancı Dil Bilgisi}

Suriyeli göçmenlerin istihdam edilmesinde, göç edilen ülkedeki dili bilmesi önemli bir üstünlük olarak değerlendirilmektedir. İşe alım süreçlerinde her ne kadar deneyim önemli bir etken olarak ifade edilse de iletişim sorunları işletme içerisinde uyumsuzluk yaratabilmektedir. Yapılan görüşmelerde bir katılımcı istihdam ettiği Suriyeli göçmenin 3 dil bilmesi ve bu durumu öne çıkartması oldukça ilginçtir.

Yanımdaki Suriyeli genç, Türkçe, Kürtçe ve Arapçayı iyi biliyor. Zaten önceden deneyimliydi. Bilmediği bir şey olduğu zaman ben öğretiyorum. (Giis 1)

Arapça biliyor. O yüzden müşterilerimle o ilgileniyor. Yanımda çalışacak Suriyelilerde dil bilmesi çok önemli. Burada en çok Arapça, Türkçe ve Kürtçe dilleri konuşulmaktadır. Bu 3 dilden en az iki dili bilmeleri çok önemli. Dediğim gibi işletmem içerisinde olumlu bir etkisi var. Çünkü dil bakımından iyiler. (Giis 11)

\subsubsection{Yerli İşçi İstihdamında Yaşanan Sorunlar}

Bazı işlerde yerlilerin çalışmaması, Suriyeli göçmenlerin istihdam edilebilmelerine imkân sağlayan bir başka etkendir. Bu işler genelde vasıf gerektirmeyen inşaat iş̧̧iliği veya hurdacılık gibi işlerdir. İ̧̧in niteliğine göre değişen ve düşen ücretler yerliler tarafından kabul edilmemekte, bu durumda ortaya çıkan açık Suriyeli göçmen çalışanlarla giderilmeye çalışılmaktadır. Odunculuk, kömürcülük ve hurdacılık işletmesi bulunan işletme sahipleriyle yapılan görüşmelerde bazı göçmen çalışanların izinsiz bir şekilde işi bırakıp, tekrar istedikleri zaman geldikleri fakat bu alanda yerli çalışan bulunamadığından çok fazla tepki gösterilmediği ifade edilmektedir.

işletme içinde 2 yıldır Suriyeli göçmen çalıştırıyorum. Yaptığımız işletme faaliyeti hurdacılık üzerinedir. Suriyeli göçmenleri işe alımda tercih ediyorum. Çünkü yerli işçiler bu işi yapmıyor. Suriyeliye verdiğimiz ücreti yerli kabul etmedi. İsimi yapamadılar. Dolayısıyla Suriyeli çalıştırıyorum. Sorun bazen kafadan işi bırakmasıdır. İinsiz işten ayrılıyor. Sonra tekrar geri geliyor. Ben de bir şey demiyorum. Ben de gel işbaşı yap diyorum. $O$ da bir şey demiyor. Tamam diyor. (Giis 10)

\subsection{Suriyeli Göçmen Girişimciler}

Suriyeliler göç ettikleri yerlere kendi geleneklerini ve kültürlerini yansıtan, kendilerine has üretim yöntemleri ile tüketim alışkanlıklarını da taşımıştır. Suriyeli göçmenler kendi milletlerinden olan kişilerin açtığı işyerlerinde dil problemi yaşamadan alışveriş yapma olanağı bulmakta, kendi gelenek ve isteklerine uygun nitelikte mal ve hizmetlerle ihtiyaçlarını karşılayabilmektedir. Aynı zamanda açılan bu işyerlerinin Suriyeli göçmenlerin istihdamına katkı sağladığı yadsınmamalıdır (Kaygısız, 2017: 14). Suriyeli göçmenler tarafından kurulan işletmelerin sayısı giderek artmaktadır. Bu durum karşısında düşüncelerini dile getiren yerli işletme sahibi "Bizler Suriyelilerden mal alma durumuna gelmişiz" şeklinde bir ifadeyle konuyu özetlemektedir. Suriyeli göçmen girişimciler küçük çaptaki işletmecilik faaliyetlerini genişleterek iş hacimlerini büyütme eğilimindedir. Bu durum göçmen girişimciliğinin daha yoğun bir şekilde irdelenmesi gerektiğini bize göstermektedir.

\subsubsection{Suriyeli Göçmenleri Girişimci Olmaya İten Sebepler}

\subsubsection{Ağır Çalışma Koşulları ve Hakkını Alamama}

Ağır çalışma koşulları ve hakkını alamama durumu, Suriyeli göçmenleri girişimci olmaya iten sebeplerin başında gelmektedir. Örneğin; Suriyeli göçmen girişimcilerden birisi Türkiye' de kendi 
işini kurmak istemesinin sebebini daha önceden Türkiye'de çalıştığı işyerlerindeki çalışma koşullarının ağırlı̆̆ına ve çalışma süresinin bazen günde 20 saati bulmasına bağlamaktadır.

Kendi işimi kurmak istedim. Çünkü başkasının yanında çalışmak istemedim ve yaşım da ilerlemiş. Daha önce kasaplık dışında Şanlıurfa'da markette çalıştım. Marketteki çalışma koşullarım çok zordu. Günde bazen 16 saat, bazen de 20 saat çalışıyordum. Hatta bazı zamanlarda market sahibi yani işveren bana: "eve gitme, burada uyu .... ne zaman seni ararsam hemen hazır ol burada" derdi. Aylık aldığım ücret ise 700 liraydı. Günlük yevmiyem 20 TL civarında oluyordu. Zam istiyordum, yapmıyordu. Birçok zaman paramı vermiyorlardı. (SGG 9)

Daha önce Türkiye'de inşaatta çalıştım işim çok zordu. Paramızı vermiyorlardı. Sabah saat 7'den akşam 6'ya kadar çalışlyorduk. Yevmiyemiz 30 TL idi. Daha önce yine Konya'da inşaat işinde abilerimle beraber çalıştık. Bizim 18 milyarımızı yediler. Paramızı vermediler. Yaptığımı işlerin hakkını alamayınca kendi işimizi kurduk. (SGG 7)

\subsubsection{Kuruluş Yeri Seçimi}

\subsubsection{Suriyelilerin Yoğunlukta Olduğu Yerler}

İşletmelerin kuruluş yeri seçiminin en önemli belirleyicilerinden birisi işletmenin sunduğu mal ve hizmetlere ilişkin talep potansiyelidir. Suriyeli göçmenlerinin yoğun olarak yaşadığı yerlerde göçmenlerin ihtiyaçlarını gideren ürünlere yönelik ihtiyaç artış göstermektedir. Bu durum da Suriyeli girişimcileri kendi işyerlerini açıp söz konusu ihtiyaçları karşılama yönünde motive etmektedir.

Şanlıurfa'da market işletiyorum. Bütün eşyalarımızı Şanlıurfa'dan temin ediyoruz. Suriyeli müş̧terilerimiz yoğunluktadır. (SGG 6)

\subsubsection{Coğrafi Yakınlık}

Suriyeli girişimciler tarafından kurularak faaliyete başlayan şirketler, çoğunlukla sınıra yakın illerdedir. Suriyeli göçmen nüfusunun en yoğun olduğu Şanlıurfa ilinde 2010 yılında, bir başka ifadeyle Suriye'deki iç karışıklıklar ortaya çıkmadan önceki dönemde, Suriyeli girişimciler tarafından açılan şirket sayısı 3 iken, 2014 yılında bu sayı 32'ye kadar çıkmıştır. Gaziantep ilindeki şirket sayısı 2012 yılında 13, 2014 yılında ise 222'ye ulaşmıştır. Mersin'de de bu duruma benzer bir artış görülmüştür. Gaziantep'in Suriye sınıra yakın en gelişmiş illerden biri olması buradaki belirleyici etken olarak görülebilir. Bu durum, Suriyeli göçmenlerin göç edilen yere ekonomik ve toplumsal açıdan uyum sağlamaya çabaladığı şeklinde yorumlanabilir. İşletme sayılarındaki artışın temel nedenleri; Suriyeli göçmenlerin ihtiyaçlarını kendi kültürlerini bilen, dillerini anlayan, zevk ve isteklerine hâkim girişimcilerden mal ve hizmet alarak karşılama talebiyle ilişkilendirilebilir. Doğal olarak karşımıza çıkan bir başka neden uluslararası ticaret kapsamındaki maliyetleri düşürme çabasıdır. Coğrafi yakınlık ulaştırma maliyetlerini düşürücü bir etki yaratmaktadır. İşletmelerin kuruluş yeri seçiminde, Suriyelilerin yoğun olarak yaşadığı yerlerden biri olan Şanlıurfa'yı tercih etmelerinin yanında sanayi bakımından gelişmiş Gaziantep iline olan yakınlık da etkili olmuştur.

Bütün eşyaları Gaziantep'ten tedarik ediyoruz. Gaziantep'te fabrika çok. Bu gördüğünüz eşyaların hepsi Gaziantep'ten gelmektedir. Markete gelen müşterilerimin hemen hemen hepsi Suriyelilerden oluşmaktadır. (SGG 3)

Yapılan bir araştırmada Suriyeli göçmenlerin daha önceden kendi topraklarında yürüttükleri ticaret faaliyetlerini, kendilerine özgü yeteneklerini gittikleri bölge veya şehirlere taşıdıkları 
ifade edilmektedir. Bu şekilde göçmenler göç edilen yerde ekonomik birer girişimci olma rolünü üstlenmektedir. Coğrafi yakınlıkla ilişkili olarak kurulan işletme sayılarının en yoğun olduğu iller sınır illeri olarak karşımıza çıkmaktadır (Özpınar vd., 2015: 2).

\subsubsection{Suriyeli Göçmen Girişimcilerin Yaşadığı Zorluklar}

\subsubsection{1. İşyeri Açma Sürecinde Yaşanan Zorluklar}

İş kurmak, girişimci olmak zor bir iştir. Girişimciliğin göç edilen bir ülkede yürütülmesi ise daha zor bir iş olarak karşımıza çıkar. İş kurma aşamasında çevredeki esnafın kendisine baskı yaptığını, izin vermediğini dile getiren Suriyeli göçmen girişimci, tercih ettiği yerde dükkân açma isteğinin 3 ay boyunca engellendiğinden söz etmektedir. Bu durum bazı bölgelerde görünmez bazı engellerin varlığına işaret etmektedir. Belli bir bölgenin sınırları dışında iş kurulabilmesi, Suriyeli göçmen işletme sahiplerinin dışlandığı şeklinde yorumlanabilir. Suriyeli göçmen girişimciler genellikle çarşının ücra köşelerinde veya işlek olmayan sokak ve caddelerde işyerlerini kurabilmektedir.

Iş kurarken en çok zorlandığım konular arasında çevrenin, esnafların baskı yapması oldu. Ilk başta dükkanımı belirlediğim bir yerde açmak istedim. Fakat izin vermediler. Biz burada aşiretiz, dediler. 2-3 ay dolandım. Sonra bir gün biri geldi ve bana destek oldu. Bana baskı kuran esnaflara ve çevreye kızdı. Onlara: "bu mahalle sizin tapulu malınız mı?" diyerek tepki gösterdi. Sonra kendi işimi kurdum. Ileride de Türkiye'de bu işimi devam ettirmek istiyorum. (SGG 9)

Suriyeli göçmen girişimcilerin işyeri açması bazı durumlarda yerel girişimcilerin müşteri kaybetmesi anlamına da gelmektedir.

Suriyelilerin buraya gelmesiyle kuaförler çoğaldı. Bu da bize olumsuz yansıdı. İşimiz azaldı. Çünkü Suriyeli kuaförler saç tıraşını ucuza yapıyor. (Giis 1)

\subsubsection{Tedarik Süreçleriyle İlgili Yaşanan Sorunlar}

Suriyeli göçmen girişimciler yaşadıkları şehir dışında, başka bir şehirden ticari amaçlı alışveriş yapabilmeleri için birtakım işlemlerin gerekli olduğunu ve bu işlemlerin de uzun sürdüğünü belirtmektedir. Bu durum girişimciler için hem zaman kaybı hem de faaliyetlerin aksaması sonucunu doğurmaktadır. Bir katılımcı, işini genişletmek istediğini fakat uzun süren işlemlerden dolayı bunu gerçekleştiremediğini ifade etmektedir. Suriyeli göçmen girişimci tüccarlara "izin" verilmeli diyerek konunun önemine değinmiştir.

Iş̧yerim için gerekli olan ihtiyaçları Şanlıurfa'dan tedarik ediyorum. Söylemek istediğim bir şey var. 31.12.2017 tarihinden önce işyerim için gerekli olan malzemeleri Türkiye'nin her ilinden getirebiliyordum. 01.01.2018 tarihinden sonra Şanlıurfa'dan başka illere gitmekte sıkıntı yaşıyorum. Bundan sonra izin alınması gerekiyor. Yani izinsiz Şanlıurfa dışına çıkamıyorum. Ve izin almak için gereken işlemler çok uzun sürüyor. Bu da işimizi aksatıyor. Tüccarlara izin verilmeli. (SGG 11)

Diğer katılımcılar da 2018 yılından itibaren bulundukları şehirden başka şehirlerle yürütecekleri ticari faaliyetlerin izin gerektirmesini bir sorun olarak ifade etmektedir.

Suriye ile iş bağlantım yok. Fakat izin sorunu yaşıyorum. Yılbaşından sonra [01.01.2018] Şanlıurfa dışında bir yere gitmekte zorlanıyoruz. Çok zamanımızı alıyor. Yani izin veriliyor ama işlemler çok uzun. Şanlıurfa'ya sıkıştım kaldım. Diğer iller bir nevi yasak. Bilmem kaymakamlığa git, bilmem şu kâğıdı getir, bilmem ne... Bir gün bile sürmeyen iş için 5 gün izin için koşuşturuyorum. (SGG 10) 
Göç İdaresi yetkilileriyle yapılan görüşmede yetkililer, giderek artan göçmen sayısından ve sistemin yeni faaliyete geçmesinden kaynaklı olarak işlemlerin uzayabildiğini belirtmiştir. Özellikle Suriyeli göçmenlerin yoğun olarak yaşadığı yerlerde bu sürecin daha uzun bir hal aldığı ifade edilmiştir.

\section{Sonuç ve Öneriler}

Çalışma hayatı bağlamında Suriyeli göçmenlerin durumunu araştırmak amacıyla 16 Suriyeli göçmen çalışan, 13 Suriyeli göçmen istihdam eden işletme sahibi ve 11 Suriyeli göçmen girişimci olmak üzere toplam 40 katılımcıyla görüşülmüştür. Yarı-yapılandırılmış görüşme tekniğiyle elde edilen görgül materyalin analiz edilmesi sonucunda Tablo 4'te özetlenen tematik örüntüye ulaşılmıştır.

Suriye'yle sınır komşusu olan ülkelerin sağladıkları koruma desteğinin yanında Almanya, ìsveç, Amerika Birleşik Devletleri ve Birleşik Krallık tarafından sağlanan, ülkeden ülkeye değişmekle birlikte oldukça sınırlı düzeyde kalmaktadır (Ostrand, 2018). Fakat Akşit vd.'nin (2015: 112) altını çizdiği gibi Suriyeli göçmenlerin varlığı geleneksel konukseverlik anlayışının ötesinde politik, sosyal ve ekonomik olarak planlanarak yönetilmesi gereken bir olguya dönüşmüştür. Bu durum Suriyeli göçmenlerin çalışma hayatı bağlamında araştırma konusu yapıımasını zorunlu kılmaktadır. Bu çalışmada göç ve çalışma hayatına ilişkin aşağıda özetlenen bulgulara erişilmiştir.

Suriyeli göçmen çalışanların çalışma motivasyonları; mecburiyet ve hayat pahalıı̆̆̆ şeklinde ifade edilen kategoriler altında toplanmıştır. Suriyeli göçmenlerin iş bulma ve çalışma yeri seçiminde ise akrabalık bağları, kültürel yakınlık, meslek değiştirme ve mesleğin devamlılı̆̆ gibi etkenlerin belirleyici olduğu görülmektedir. Suriyeli göçmenlerin Şanlıurfa'yı göç için tercih etmelerinin en önemli sebeplerinden birisi var olan akrabalık bağlarıdır. Suriyeli göçmenlerin göç ettikleri ülkedeki çalışma hayatları çeşitli sorunları da beraberinde getirmektedir. Emek sömürüsü, farklı ücretlendirme, kültürel farklılıklar, iletişim sorunları, iş yapış tarzındaki farklılıklar, farklı ülkede çalışma, yerli çalışanların olumsuz tutumları temel olarak bu çalışma kapsamında vurgulanan sorunlar arasındadır. Tüm bu sorunlara rağmen işletmeler mesleki tecrübe, destek olmak arzusu, müşteri çekme potansiyeli, yabancı dil bilgisi ve yerli işçi istihdamında yaşanan sorunlar nedeniyle Suriyeli göçmenleri istihdam etmektedir. Suriyeli göçmenler Şanlıurfa'da sadece çalışmamakta aynı zamanda girişimci olarak kendi işlerini kurma yolunu da tercih edebilmektedir. Suriyeli göçmenler deneyimledikleri ağır çalışma koşulları ve hakkını alamama durumuna son vermek adına kendi işini kurma yolunu seçmektedir.

Araştırma sonunda ortaya çıkan bulgular aracılığıyla çalışma hayatı ile uluslararası düzensiz göç ilişkisi, alanyazında üzerinde durulan kuramlarla birlikte yorumlanmalıdır. Örneğin, uluslararası itme-çekme yaklaşımında olduğu gibi, itici faktörlerden olan Suriyelilerin kendi ülkelerindeki siyasi sebeplerden dolayı ortaya çıkan güvensizlik ortamı ile Şanlıurfa'ya göç etmesindeki çekici bir faktör olan güvenli yerin oluşu göç etme kararının verilmesinde etkili olmuştur. Ayrıca bu yaklaşımda yolculuk maliyetinin düşük olması, dil ve kültürel benzerlikler de göçü tetikleyen diğer nedenler olarak ortaya çıkmıştır.

Araştırmanın sonuçlarının, alanyazındaki diğer kuramlarla da yakından ilişkili olduğu görülmüştür. Ravenstain'ın göç kanunlarında belirtilen; kısa mesafeli göçler göç dalgası etkisi yaratır, ilkesi Türkiye ile Suriye arasındaki sınırsal yakınlıkla ilgilidir. Göçmenlerin bu doğrultuda Şanlıurfa ilinde kısa sürede çoğalması da bu durumla ilişkilendirilebilir. Göç sistemleri teorisi bakımından Şanlıurfa'daki göçmenlerin durumu incelendiğinde akraba ve aile kökenli bağların göç 
etme kararındaki önemi ortaya çıkmaktadır. Ülkeler arasındaki sınırsal yakınlığın bulunduğu yerlerde bu bağlar kendini göstermektedir. Özellikle Şanlıurfa gibi sınıra yakın olan yerlerdeki sosyal bağlantıların var olması göçün bu yerlerde yoğunlaşmasına neden olmuştur.

Her görgül çalışmada olduğu gibi bu çalışmanın da bazı sınırıııkları vardır. Tüm çabalara rağmen görüşme süreleri beklenenin ve alanyazında önerilenin altında kalmıştır. Görüşme sürelerinin kısa ve katılımcıdan katılımcıya farklılık gösterme sebepleri; katılımcılarla 3 farklı dilde (Türkçe, Kürtçe ve Arapça) görüşme yapılmış olması, bazı durumlarda görüşmelerin tercüman eşliğinde gerçekleştirilmesi, çalışanlarla onların iş yerlerinde ve onlar faal olarak çalışırken görüşülmüş olması şeklinde özetlenebilir. Bu kısıt çok sayıda katılımcıyla görüşülerek aşılmaya çaış̧ımıştır. Gelecek çalışmalarda daha az sayıda katılımcıyla daha uzun süreli görüşmeler aracılığıyla fenomenolojik çalışmalar yapılması önerilebilir.

Çalışma kapsamında uygulamaya dönük bazı öneriler de belirlenmiştir. Örneğin, Suriyeli göçmenlere yönelik dil eğitimi ile mesleki eğitim yaygınlaştırılmalıdır. Etnik söylemlerin önüne geçilmesi için çaba harcanmalıdır. Özellikle Suriyeli göçmenlerin yoğun olarak yaşadıkları illerde yerli halk ile Suriyeli göçmenlerin birlikte çalışabilecekleri iş fırsatları ve iş birliği olanakları yaratılmalıdır. 


\section{Eskişehir Osmangazi Üniversitesi IïB Dergisi}

\section{Kaynaklar}

Akşit, Gökçesu; Bozok, Mehmet; Bozok, Nihan (2015). “Zorunlu Göç, Sorunlu Karşılaşmalar: Hisar Köyü, Nevşehir'deki Suriyeli Göçmenler Örneği", TC. Maltepe Üniversitesi Fen-Edebiyat Fakültesi Dergisi C. 1., S. 2: 92-116.

Aydoğanoğlu, E. (2007). Uluslararası Emek Göçü, Yasadışı Göç ve Göçmen İstihdamı. http://www.emekdunyasi.net/ed/arastirmalar/593-uluslararasi-emek-gocu-yasadisi-goc-ve-gocmen-istihdami-1 (Erişim Tarihi, 20.11.2017).

Barın, Hilal (2015), "Türkiye'deki Suriyeli Kadınların Toplumsal Bağlamda Yaşadıkları Sorunlar ve Çözüm Önerileri”, Göç Araştırmaları Dergisi, C. 1, S. 2: 10-56.

Bahcekapılı, Cengiz; Çetin, Buket (2015), "The Impacts of Forced Migration on Regional Economies: The Case of Syrian Refugees in Turkey", International Business Research, Vol. 8, No: 9: 1-15.

Boz, Dicle (2016), “Dış Göçler Olgusu ve Etkisi: Türkiye-Suriye Üzerine Bir İnceleme”, Sosyoekonomi Dergisi, C. 24, S. 30 : 147-153.

Canefe, Nergis (2016), "Management of Irregular Migration: Syrians in Turkey as Paradigm Shifters for Forced Migration Studies", New Perspectives on Turkey, No. 54: 9-32.

Castles, Stephen; Miller, J. Mark, (2008), Göçler Çağı: Modern Dünyada Uluslararası Göç Hareketleri. İstanbul: İstanbul Bilgi Üniversitesi Yayınları.

Coşkun, Remzi; Altunışık, Recai; Bayraktaroğlu, Serkan; Yıldırım, Engin (2015), Sosyal Bilimlerde Araştırma Yöntemleri SPSS Uygulamalı, 8. Baskı, Adapazarı: Sakarya Kitabevi Yayıncılık.

Creswell, John W (2013), Nitel Araştırma Yöntemleri: Beş Yaklaşıma Göre Nitel Araştırma Deseni (Çev: M. Bütün ve S. B. Demir). Ankara: Siyasal Kitabevi.

Çakılcı, Emin (2017), “Dış Göç Bağlamında Türkiye'nin Geçiş Yılları ve Göçmenlerin İstihdamdaki Görünümleri”, SOBiDER Sosyal Bilimler Dergisi, C. 4, S. 10: 463- 476.

Çakır, Sabri (2011), "Türkiye'de Göç, Kentleşme/Gecekondu Sorunu ve Üretilen Politikalar”, Süleyman Demirel Üniversitesi Fen Edebiyat Fakültesi Sosyal Bilimler Dergisi, No. 23: 209-222.

Deniz, Cengiz. (2015). Zorunlu Göçün Mekânsal Etkileri Ve Yerel Halkın Algısı; Kilis Örneği, Turkish Studies: International Periodical For The Languages, Literature and History of Turkish or Turkic, Vol. 10, No. 2: 101-122.

Diken, Ahmet; Demirel, Ebru (2016), “Işsletmelerimizde Nitelikli İşgücü ỉhtiyacı ve Suriyeli Göçmen İş Görenlerin İşgücü Piyasasına Etkisi Üzerine Bir Araştırma”, 2. Uluslararası Uygulamalı Bilimler Kongresi: Göç, Yoksulluk ve İstihdam, 23-25 Eylül, Konya: Necmettin Erbakan Üniversitesi: 51-60.

Fawcett, James T.; Arnold, Fred (1987), "Explaining Diversity: Asian and Pacific Immigration Systems", Center For Migration Studies Special Issues, Vol. 5, No: 3: 453-473.

Göç İdaresi Genel Müdürlüğü, (2016). Türkiye Göç Raporu. Ankara: Göç İdaresi Genel Müdürlüğü Yayınları.

Guba, Egon G. (1981), "Criteria for Assessing the Thrustworthiness of Naturalistic Inquiries" Educational Communication and Technology Journal, Vol. 29, No. 2: 75-91.

Guest, Greg; Bunce, Arwen; Johnson, Laura (2006), “How Many Interviews Are Enough?: An Experiment with Data Saturation and Variability", Field Methods, Vol. 18, No: 1: 59-82.

HÜGO (2014). Türkiye'deki Suriyeliler. http://www.hugo.hacettepe.edu.tr/HUGO-RAPORTurkiyedekiSuriyeliler.pdf. (Erişim tarihi: 08.11.2017).

İçduygu, Ahmet; Diker, Eleni (2017), “Türkiye'deki Suriyeli Mültecilerin İşgücü Piyasası Entegrasyonu Mültecilikten Göçmenliğe”, Göç Araştırmaları Dergisi, C. 3, S. 1: 12-35.

Kaygısız, İrfan (2017), Suriyeli Mültecilerin Türkiye Işsücü Piyasasına Etkileri, Fredrich Ebert Stiftung Vakfı. http://www.fes-tuerkei.org/media/pdf/D\%C3\%BCnyadan/2017/Du308nyadan\%20-\%20Suriyeli\%20Mu308/tecilerin\%20Tu308rkiye\%201307s327gu308cu308\%20Piyasasina\%20Etkileri\%20.pdf (Erişim tarihi: 18.12. 2017).

Kaynak, Selahattin; Arslan, İbrahim; Alancıoğlu, Erdal; Koçakoğlu, M. Ali (2016), “Göçün Sosyo-ekonomik Sonuçları: Suriyeli Göçmenler", 2. Uluslararası Uygulamalı Bilimler Kongresi: Göç, Yoksulluk ve Istihdam, Konya: Necmettin Erbakan Üniversitesi: 11-18.

Lee, Everett S. (1966), “A Theory of Migration”, Demography, Vol. 3, No. 1: 47-57.

Lincoln, Yvonna. S.; Guba, Egon G. (1985). Naturalistic Inquiry. Beverley Hills, CA: Sage.

Lordoğlu, Kuvvet; Kıroğlu, M. Meryem; Tanyılmaz, Kurat (2004), Türkiye'de Enformel Istihdam ve Yabancı Kaçak Işgücü, İstanbul: UGINAR Proje Raporu. 
Lordoğlu, Kuvvet; Aslan Mustafa (2016), "En Fazla Suriyeli Göçmen Alan Beş Kentin Emek Piyasalarında Değişimi”, ÇaIışma ve Toplum Dergisi, C. 49, S. 2: 789-808.

Merriam, S. B. (2002). Qualitative Research and Case Study Applications in Education. San Francisco, CA: Jossey-Bass.

Oytun, Orhan; Senyücel-Gündoğar, Sabiha (2015), Suriyeli Sığınmacıların Türkiye'ye Etkileri. Ankara: Ortadoğu Stratejik Araştırmalar Merkezi.

Ostrand, Nicole (2015) "The Syrian Refugee Crisis: A Comparison of Responses by Germany, Sweden, the United Kingdom, and the United States", Journal on Migration and Human Security, Vol. 3, No: 3: 255-279.

Özpınar, Esra; Başıhoş, Seda; Kulaksız Aycan (2015), Göçün Ardından Suriye ile Ticari ilişkiler. Türkiye Ekonomi Politikaları Araştırma Vakfı.

Pınar, Abuzer; Siverekli, Esra; Demir, Murat (2016), Şanlıurfa'da İşverenlerin ve Iş̧̧ilerin Suriyeli istihdamına Bakışı. ILOTürkiye Ofisi.

Rittersberger-Tılıç, Helga (2015), "Managing' Irregular Labor Migrants in Turkey”, Göç Araştırmaları Dergisi, C. 1, S. 1: 80-107.

TÜiK, 2014. Seçilmiş Göstergelerle Şanlıurfa 2013. http://www.tuik.gov.tr_(Erişim tarihi: 10. 11. 2017).

TÜiK, 2015-2016. Illerin Aldığı ve Verdiği Göç. http://www.tuik.gov.tr_(Erişim tarihi: 11.11.2017).

Weiner, Myron (1985), “On International Migration and International Relation”, Population and Development Review, Vol. 11, No. 3: 441-455.

Yalçın, Cemal (2004), Göç Sosyolojisi, Ankara: Anı Yayıncılık.

Yaman, Ahmet (2016), "Suriyeli Sosyal Sermayenin İnşası ve Yeniden Üretim Sürecinin Sivil Toplum ve Ekonomik Hayat Alanlarında İncelenmesi", Göç Araştırmaları Dergisi, C. 2, S. 3: 94-127.

Yıldırım, Ali; Şimşek, Hasan (2016), Sosyal Bilimlerde Nitel Araştırma Yöntemleri, 10.Baskı, Ankara: Seçkin Yayıncılık.

http-1:http://www.goc.gov.tr/icerik6/duzensiz-goc_363_378_4710_icerik 30.10.2017. 
Eskişehir Osmangazi Üniversitesi IißBF Dergisi 